\title{
KEPEMIMPINAN SPIRITUAL PADA PESANTREN MAHASISWA(Studi Multsitus pada Pesantren Mahasiswa Ulul Albab, Ulul Yaqin dan Ulul Hikam Malang)
}

\author{
Mokhamad Endri Julianto \\ e-mail: \\ Universitas Islam Malang
}

\begin{abstract}
:
Spiritual leaders are leaders who influence people led by inspired, enlighten, awaken, enabling, and empowering through the approach of spirituality or religious ethical values. This research was conducted in three boarding students, in student boarding Ulul Albab, Ulul Yaqin and Ulul Hikam in Malang, East Java, using a qualitative approach. This study was designed wearing a multi-site study. Once the data as a whole has finished checking, the data collected were analyzed, with analysis of the site as well as inter-site analysis. From the research result shows that: (1) Perspective spiritual leadership is a boarding student. (2)Spirituality actualization ofleadership in the assembly caregivers (3) Typology of leadership tends to behavior leadership of participative colleguelike - democratic - spiritual religion (4) Decision-making (5) Settlement of individual conflicts (6) The development team (7) Variety of spiritual leadership in organizational culture (8) The value system of spiritual leadership, and (9) There are several obstacles and solutions in spiritual leadership at the boarding (pesantren) students.
\end{abstract}

Keyword:spiritual leadership, organization culture, student of islamic boarding school,

\begin{abstract}
Abstrak:
Pemimpin spiritual adalah para pemimpin yang mempengaruhi orang yang dipimpin oleh terinspirasi, mencerahkan, terbangun, memungkinkan, dan memberdayakan melalui pendekatan spiritualitas atau nilai-nilai etika agama. Penelitian ini dilakukan dalam tiga siswa asrama, di mahasiswa kos Ulul Albab, Ulul Yaqin dan Ulul Hikam di Malang, Jawa Timur, menggunakan pendekatan kualitatif. Penelitian ini dirancang mengenakan studi multi-situs. Setelah data secara keseluruhan telah selesai memeriksa, data yang dikumpulkan dianalisis, dengan analisis situs serta analisis antar situs. Dari hasil penelitian menunjukkan bahwa: (1) kepemimpinan spiritual Perspektif adalah mahasiswa asrama. (2) Spiritualitas aktualisasi kepemimpinan dalam perakitan pengasuh (3) Tipologi kepemimpinan cenderung kepemimpinan perilaku rekan partisipatif seperti - demokratis - agama spiritual (4) Pengambilan keputusan (5) Penyelesaian konflik individual (6) Tim pengembangan ( 7) Ragam kepemimpinan spiritual dalam budaya organisasi (8) Sistem nilai kepemimpinan spiritual, dan (9) Ada beberapa hambatan dan solusi dalam kepemimpinan spiritual di asrama (pesantren) siswa.
\end{abstract}

Kata kunci: kepemimpinan spiritual, budaya organisasi, mahasiswa pondok pesantren

\section{Pendahuluan}

Keberadaan Pesantren Mahasiswa sebagai organisasi dan lembaga keagamaan atau organisasi mulia (noble industry), selama ini telah menempatkan posisinya sederajat dengan lembaga pendidikan pada umumnya; memiliki budaya, iklim, model organisasi, dan struktur kepemimpinan yang khas untuk mencapai tujuan yang efektif. Peran serta pesantren mahasiswa juga menberikan konstribusi besar dalam melaksanakan pendidikan manusia seutuhnya di Republik Indonesia. 
Beberapa hasil penelitian menunjukkan hubungan yang signifikan antara kepemimpinan yang efektif dengan organisasiyang efektif. Penelitian Edmonds (1979:28) mengemukakan bahwa organisasi-organisasi yang dinamis yang senantiasa berupaya meningkatkan prestasi kerjanya dipimpin oleh pemimpin yang baik. Demikian pula penelitian Hallinger dan Lithwood (1994) yang menyimpulkan bahwa organisasi yang efektif senantiasa dipimpin oleh manajer yang efektif pula. Kedua penelitian tersebut didasarkan pada asumsi bahwa pemimpin merupakan agen perubahan yang terpenting.

Pemimpin yang memiliki kepemimpinan yang kuat menurut Blumberg dan Greenfield (1980) adalah orang yang mampu memerankan diri dalam delapan peran: organisator (the organizer), pengakrobat berdasarkan nilai (the value-based juggler), penolong sejati (theauthentic helper), perantara (the broker), humanis (the humanist), katalis (thecatalyst), rasionalis (the rationalist), dan politicus (the politician). Model kepemimpinan ini menurut Percy (1997) adalah kepemimpinan yang memiliki kedalaman spiritualitas atau the corporate mystic menurut Hendricks dan Ludeman (1996). Kepemimpinan dimensi keempat menurut Henry Tjahjono (2003) adalah kepemimpinan yang mengembangkan kecerdasan emosi menurut Goleman (2003), executive $E Q$ menurut Cooper dan Sawaf (2002) dan powerful leaders menurut Ary Ginanjar Agustian (2004). The Spiritual Leadership (Tabroni, 2005). Muhammad SAW The Super Leader-Super Manager (Antonio, 2007). Muhammad Prophetic Leadership membentuk kepribadian para pemimpin berbasis spiritualitas (Al-Banjari, 2008).

Sementara Zohar dan Marshal (2000: 3-4) menyebut kecerdasan spiritual sebagai the ultimate intelligence. Kalau dalam diri manusia terdapat ketiga "jurus" kecerdasan yaitu kecerdasan intelektual (intellectual quotient, IQ), kecerdasan emosional (emotional quotient, EQ), dan kecerdasan spiritual (spiritual quotient, SQ), maka kata Zohar dan Marshal, SQ merupakan fondasi yang diperlukan bagi keefektifan dua kecerdasan yang lain, "SQis the necessary foundation for the functioning of both IQ and EQ. It is our ultimate intelligence". Hendricks dan Ludeman (1996) menyatakan bahwa kepemimpinan spiritual juga bisa diartikan sebagai kepemimpinan yang sangat menjaga nilainilai etis dan menjunjung tinggi nilai-nilai spiritual.

Berdasarkan pendapat tersebut, ada dua hal yang menjadi pembahasan menyangkut sosok kyai (pengasuh) atau ulama' sebagai pemimpin spiritual di pesantren mahasiswa yaitu; spiritualleadership (kepemimpinan spiritual) sebagai sebuah perilaku, dan budaya organisasi pesantren mahasiswa yang kental dengan nilai-nilai spiritual atau spiritualitas kepemimpinan yang membudaya pada organisasi pesantren mahasiswa. Ada tiga fokus terbagi dalam beberapa sub fokusyang perlu dijawab dalam penelitian ini yakni; (1) tipologi kepemimpinan, yang terdiri dari: (a) perspektif kepemimpinan spiritual, (b) spiritualitas kepemimpinan, (c) tipologi kepemimpinan spiritual; (2) tugas dan fungsi kepemimpinan spiritual dalam proses: (a) pengambilan keputusan (b) pengendalian konflik, dan (c) pembangun tim; (3) Sistem nilai spiritual kepemimpinan dalam budaya organisasi pesantren mahasiswa yang meliputi: (a) ragam nilai spiritual kepemimpinan dalam budaya organisasi pesantren mahasiswa, (b) sistem nilai kepemimpinan spiritual dalam budaya organisasi pesantren 
mahasiswa, (c) hambatan dan solusi penerapan nilai-nilai kepemimpinan spiritual di pesantren mahasiswa.

\section{Metode}

$\begin{array}{clr}\text { Untuk } & \text { dapat } & \text { mengungkap } \\ \text { permasalahan } & \text { tersebut } & \text { digunakan }\end{array}$ pendekatan penelitian kualitatif dengan rancangan fenomenologis atau naturalistik yang disifatkan pada multisitus. Dalam penelitian ini, terdapat 3 (tiga) situs yakni pesantren mahasiswa Ulul Albab, Ulul Yaqin, dan Ulul Hikam. Penelitian ini menggunakan rancangan studi multisitus, seperti ditegaskan oleh Bogdan dan Biklen (1998:62) bahwa:

When researchers study two or more subjects, settings, or depositories of data they are usually doing what we call Multi Site Studies. Multi site studies take a variety of forms. Some start as a single site only to have the original work serve as the first in series of studies or as the pilot for a multi-site study. Other studies are primarily single-site studies but indude less intense, less extensive observations at other sites for the purpose of addressing the question of general izability. Other researchers do comparative site studies. Two or more site studies are done and then commpared and contrasted.

Peneliti bertindak sebagai instrumen kunci (key instrument) yang berfungsi menetapkan fokus penelitian, memilih situasi sosial dan informan sebagai sumber data, melakukan pengumpulan data, menilai kualitas data, analisis data, menafsirkan data, dan membuat kesimpulan dari hasil temuan di lapangan (Moleong, 1994). Dalam pengumpulan data penelitian ini dilakukan tiga teknik, yaitu: (1) wawancara mendalam (indepth interviewing; (2) observasi partisipan (participant observation);dan(3) studi dokumentasi (study of documents). Untuk mengecek atau memeriksa keabsahan data mengenai kepemimpinan spiritual di Pesantren Mahasiswa berbasis nilai-nilai spiritual berdasarkan data yang terkumpul, selanjutnya ditempuh beberapa teknik keabsahan data, meliputi: kredibilitas, transferabilitas, dipendabilitas, dan konfirmabilitas (Lincoln \& Guba, 1985 : Moleong, 1993).

Langkah-langkah analisa data lintas situs penelitian ini dapat digambarkan sebagai berikut: 


\section{Gambar 1. Langkah-langkah analisa data lintas situs penelitian}

Situs 1: Pesma Ulul Albab

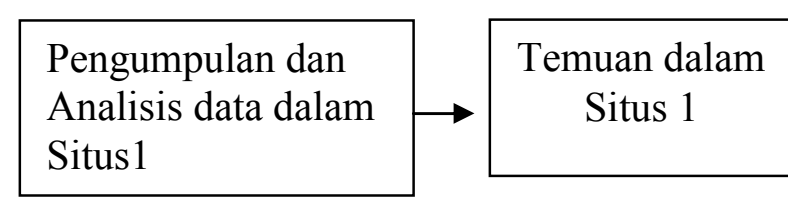

Situs 2: Ulul Yaqin

\begin{tabular}{|l|l|}
\hline $\begin{array}{l}\text { Pengumpulan dan } \\
\text { Analisis data } \\
\text { dalam Situs } 2\end{array}$ & $\rightarrow$ \\
$\begin{array}{c}\text { Temuan } \\
\text { dalam Situs } 2\end{array}$ \\
\hline
\end{tabular}

Situs 3: Pesma Ulul Hikam

\begin{tabular}{|c|c|}
\hline $\begin{array}{l}\text { Pengumpulan dan } \\
\text { Analisis data } \\
\text { dalam Situs } 3\end{array}$ & $\begin{array}{c}\text { Temuan dalam } \\
\text { Situs } 3\end{array}$ \\
\hline
\end{tabular}

Perlu dijelaskan dalam penelitian kualitatif, sebagaimana dalam penelitian ini, semua nama lembaga disamarkan dengan maksud memberikan perlindungan dan kenyamanan bagi pihak lembaga dengan tetap menjaga kredibilitasnya di mata pembaca, untuk itu keberadaan lokasi dan lembaga dalam penelitian ini menggunakan nama samaran.

\section{Pembahasan}

1. Tipologi Kepemimpinan

a. Perspektif kepemimpinan spiritual di pesantren mahasiswa

Ketua majelis pembina atau majelis pengasuh dalam melaksanakan kepemimpinan (leadership) dan kepengasuhan (parenting)dibantu oleh seorang sekretaris dan beberapa anggota; ketua majelis pengasuh dijabat oleh rektor dan atau ketua yayasan, sekretaris dari pembantu rektor I/bidang akademik dan anggota dari pembantu rektor II dan III serta beberapa kyai senior (masyayikh), tergabung dalam majelis pembina/majelis pengasuh pesantren mahasiswa. Majlis pengasuh di pesantren mahasiswa adalah lembaga tertinggi yang secara umum berfungsi sebagai nadhir wakaf dan aset pesantren, sebagai pembina pengurus harian, sebagai penjaga aqidah dan qaidah kepesantrenan dengan dilandasi nilainilai spiritual yang dimanifestasikan melalui visi, misi dan tujuan pesantren mahasiswa, serta sebagai penentu kebijakan di pesantren mahasiswa.

Perspektif kepemimpinan spiritual ini mendukung terhadap teori kepemimpinan yang relevan di masa moderen ini. Sebagaimana Abu Sinn (1996) mendefinisikan kepemimpinan sebagai sebuah sistem dan bukanlah unsur tunggal yang memberikan pengaruh 
kepada orang lain, melainkan ia juga dipengaruhi oleh pendapat masyarakat, karena seorang pemimpin adalah bagian dari anggota masyarakat (jama'ah) yang saling berkontribusi, bertukar pendapat, dan pengalaman, serta bersama-sama berusaha mewujudkan tujuan bersama. Dalam konteks penelitian ini adalah tujuan bersama pada organisasi pesantren mahasiswa, yakni organisasi pesantren mahasiswa yang terindikasikan berbasis nilai-nilai spiritual.

Tabroni (2005: 239) menuturkan bahwa gaya kepemimpinan spiritual didasarkan pada nilai-nilai ketuhanan, mencontoh kepemimpinan Tuhan dan menjadi "pipa" penyalur rahmat Tuhan. Kepemimpinan spiritual dapat menciptakan noble industry yang efektif. Standar keefektifan ini diukur dalam tiga hal: budaya organisasi yang kondusif, proses organisasi yang efektif dan inovasiinovasi dalam organisasi.

Perspektif kepemimpinan spiritual di sebagian pesantren, sebagaimana hasil penelitian ini, kiranya telah menjawab kekhawatiran masyarakat terhadap sistem kepemimpinan pesantren selama ini, sebagaimana pandangan Abd A'la (2006) bahwa manajemen (kepemimpinan) pesantren, meski tidak semua, selama ini dikelola seadanya dengan kesan menonjol pada penanganan individual dan bernuansa kharismatik.

b. Spiritualitas kepemimpinan Spiritualitas kepemimpinan teraktualisasi dalam mempengaruhi orang yang dipimpin dengan cara memotivasi agar memiliki semangat yang tangguh pada bawahan dan warga pesantren mahasiswa, mencerahkan suasana dengan menciptakan atmosfer organisasi yang kondusif, pengarah visi/misi/tujuan organisasi agar terfokus, membangkitkan semangat untuk meningkatkan kualitas sumber daya manusia warga pesantren mahasiswa melaui keterampilan hidup (lifeskill) dan peningkatan keilmuan dan pengamalan keagamaan, memampukan kemandirian santri dengan memberikan sarana prasarana pesantren mahasiswa dan meningkatkan pemasukan para ustadz untuk menambah kesejahteraan mereka, secara makro sebagai upaya untuk mewujudkan visi, misi, dan tujuan organisasi pesantren mahasiswa menjadi semakin maju dan bermutu serta memberikan kontribusi pada masyarakat, bangsa dan Negara serta agama dilandasi dengan nilai-nilai spiritualitas keagamaan Islam.

Dalam hal mutu atau kualitas organisasi pesantren mahasiswa dapat didiskusikan sebagai berikut. Mutu berasal dan bahasa Latin, qua/is, yang artinya What kind of. Mutu, menurut Deming, ialah kesesuaian dengan kebutuhan pasar. Sementara itu menurut Juran disebutkan sebagai kecocokan dengan produk. Adapun dalam pandangan Crosby ialah kesesuaian dengan yang diisyaratkan (Usman, 2007). Dalam bahasa Inggris, mutu sepadan dengan kata quality (kualitas). Definisi kualitas yakni; perfection; concistency; eliminating waste; speed of delivery; compliance with policies and procedures; providing a good; doing it right the first time; delighting or pleasing customers dan total customer service and satisfaction (Vans dan Dean, 2003; Purnama, 2006). Beberapa hal yang dapat mempengaruhi mutu secara umum adalah "3 Cs of TQM", yaitu culture, commitment dan communication (Murgatroyd dan Morgan, 1994; Mantja, 2007). Budaya yang dimaksud di sini meliputi aturan, asumsi dan nilai yang mengikat kebersamaan dalam organisasi. Komitmen berarti keterlibatan menanggilng akibat dalam pencapaian tujuan. The American Sociaty of Quality Control menyatakan bahwa kualitas adalah keseluruhan ciri- 
ciri dan karakteristik dan suatu produk atau layanan menyangkut kemampuan untuk memenuhi kebutuhan-kebutuhan yang telah ditentukan atau bersifat laten (Evans \& Dean, 2003; Purnama, 2006). Mutu adalah sebuah hal yang berhubungan dengan gairah dan harga diri (Tom Peters dan Nancy Austin,1985; Sallis, 2006). Arcaro mendefinisikan mutu adalah sebuah proses terstruktur untuk memperbaiki keluaran/lulusan yang dihasilkan. Secara umum, mutu adalah gambaran dan karakteristik rnenyeluruh dan barang atau jasa yang menunjukkan kemampuannya dalam memuaskan kebutuhan yang diharapkan atau yang tersirat. Secara esensial, istilah mutu menunjukkan kepada suatu ukuran penilaian atau penghargaan yang diberikan atau dikenakan kepada barang (products) dan atau jasa (services) tertentu bahkan pertimbangan objektif atas bobot dan atau kinerjanya (Preffer, 1991; Komariah, 2005). Mutu dalam penerapannya dapat dikatakan sebagai mutu mutlak/absolut dan mutu relatif. Ukuran mutu absolut sulit diterapkan dalam dunia pendidikan dengan penilaian dan berbagai pihak dan manajemen jasa yang heterogen. Oleh karena itu, digunakan mutu relatif yaitu berkaitan dengan kebutuhan pelanggan yakni; kepala sekolah/madrasah, guru, tenaga kependidikan, karyawan, peserta didik, orang tua dan steakholders(Komariah, 2005). Dalam konteks pendidikan, pengertian mutu mencakup input, proses, dan outputpendidikan (Dirjen Dikdasmen, 2002).

c. Tipologi kepemimpinan spiritual Beberapa perubahan kecenderungan atau tidak bersifat "fixed" perilaku kepemimpinan spiritual dalam majelis pembina/ majelis pengasuh. Kecenderungan bergantung pada kapasitas peran dan otoritas dan kewenangan yang diberikan atau didelagasikan pada pengurus harian. Penelitian ini secara praktis mempertegas hasil penelitian Mastuhu (1989) dari enam pesantren, ditemukan perilaku kepemimpinan berbeda secara graduatif, serta adanya kecenderungan perubahan gaya kepemimpinan; dari kepemimpinan kharismatik ke rasionalistik, dari otoriterpaternalistik ke diplomatik-partisipatif, dan dari laisser-Faire ke birokratif. Sejalan dengan hasil penelitian kepemimpinan yang dilakukan Sukamto(1999) pada Pesantren Darul Ulum Jombang, bahwa akar kepemimpinan pesantren berasal dari akar yang sama dengan pondok pesantren di Jawa dan Madura yaitu dari kepemimpinan kharismatik dan pada perkembangan gaya kepemimpinannya dari generasi ke generasi menggunakan gaya kepemimpinan legal formal (kolegial). Penegasan terhadap hasil penelitian di atas terletak pada partisipasi pengurus, sehingga semakin luas partisipasi pengurus memungkinkan tipologi kepemimpinan spiritualdemokratis, semakin bebas partisipasi pengurus, memungkinkan tipologi kepemimpinan spiritual-laissezffaire, dan semakin terikat partisipasi pengurus, memungkinkan perilaku kepemimpinan spiritual-otokratis.

Selama ini perilaku kepemimpinan demokratis dianggap satu-satunya perilaku kepemimpinan yang paling baik, sementara perilaku otokratis dalam kepemimpinan dianggap satu-satunya perilaku kepemimpinan yang paling jelek. Sedangkan perilaku kepemimpinan laissezffaire kurang mendapat perhatian serius dari peneliti sosial manajemen apakah kurang baik atau kurang jelek.

Perilaku kepemimpinan demokratis menurut Duncan (1981) pada umumnya diasumsi bahwa pendapat 
orang banyak lebih baik dari pendapat sendiri dan adanya partisipasi akan menimbulkan tanggung jawab bagi pelaksananya, atau asumsi lain bahwa partisipasi memberikan kesempatan kepada para anggota untuk mengembangkan diri mereka sendiri.

Perilaku kepemimpinan spiritual di pesantren yang direpresentasikan dari majelis pengasuh dapat diasumsi sebagai tipologi kepemimpinan demokratis. Hal ini karena kyai atau pemimpin tidak memimpin pesantren secara individual, melainkan memimpin dengan beberapa kyai atau beberapa pemimpin. Sebagaimana penelitian S. Dhofir (2004) tentang kekuasaan dan otoritas kyai dalam pesantren, bahwa kekuasaan kyai tidak terpusat pada satu figur kyai atau seorang pemimpin, melainkan ada dalam kepemimpinan spiritual, yang berwujud majelis pengasuh.

Relevan kiranya apabila konteks kepemimpinan spiritual di pesantren mahasiswa ini disandingkan dengan theory management syistem Likert (1967) dengan menggunakan prinsip dasar leadership continoum. Hal ini dapat digunakan sebagai bahanperbandingan untuk menentukan karakteristik perilaku kepemimpinan majelis pengasuh dalam pesantren, apakah perilaku kepemimpinan spiritual bersifat partisipatif-otokratis, kepemimpinan spiritual bersifat partisipatif-demokratis, dan atau kepemimpinan spiritual bersifat partisipatif-liberal.

2. Tugas dan Fungsi Kepemimpinan dalam Proses; Pengambilan Keputusan, Pengendalian Konflik, dan Pembangun Tim

a. Proses pengambilan keputusan (decision making) di pesantren mahasiswa

$$
\text { Menurut Rivai (2003), }
$$

pengambilan keputusan dalam tinjauan perilaku mencerminkan karakter bagi seorang pemimpin. Oleh karena itu, untuk mengetahui apakah keputusan yang diambil baik atau buruk, tidak hanya dinilai setelah konsekuensinya terjadi, melainkan juga melalui berbagai pertimbangan dalam prosesnya.

Dalam Islam, sebelum melakukan tindakan dan keputusan disyari'atkan berikhtiar. Bahkan di kalangan kyai "tradisionalis", ikhtiar ini masih menjadi perilaku tasawuf yang masih dipegang teguh, karena mereka yakin akan firasat kyai tertentu. Firasat ini dalam konteks manajemen senantiasa diformulasi sebagai forescasting (peramalan) sebelum melakukan tindakan dan keputusan (Mochtar Effendy, 1985), bahkan Rasul Muhammad saw. bersabda; "takutlah oleh kamu akan firasat seseorang yang beriman, karena dia melihat nor Ilahi" (al-Hadits). Dikatakan oleh Imam Waqiq guru Imam Syafi'i; "Al ilmu nur wa nurullahi laa yahtahdil ma'atsi" (ilmu itu adalah cahaya dan cahaya Allah tidak akan diberikan pada orang yang suka maksiat)

Perilaku demikian ditemukan dalam pesantren. Para kyai yakin bahwa dengan firasat merupakan ilmu Allah swt., yang diilhamkan kepada manusia suci (mu'min) yang dikehedaki-Nya. Oleh karena itu, telah menjadi kebiasaan yang baik bagi seorang muslim dalam menghadapi suatu persoalan yang musykil (permasalahan) untukmeminta petujuk kepada Allah dengan jalan sembahyang istikharah dua raka'at, untuk mendapatkan petunjuk dan hidayah-Nya, untuk mengambil keputusan atau merencanakan sesuatu. Kebiasaan yang demikian akan membawa kepada suatu perilaku dan sikap taqarrub (approach) selalu dekat kepada Allah swt., dan membiasakan diri untuk tidak mengambil tindakan gegabah.

Para kyai diyakini sebagai muslim yang ta'at, dalam mengambil keputusan 
sepatutnya melakukan musyawarah kelompok. Menurut Abu Sinn (2006), bermusyawarah merupakan suatu kewajiban, hal ini berdasar pada kapasitas akal fikir dan intelektual manusia yang terbatas dalam menguasai semua persoalan, dan pendapat orang banyak lebih bisa dipertanggung jawabkan daripada pendapat pribadi.

b. Pengendalian konflik (conflict control) di pesantren mahasiswa

Konflik dalam konteks pesantren mahasiswa, diartikan sebagai kesalahpahaman, maka diperlukan suatu keilmuan tentang penyelesaian konflik atau pengelolaan konflik (management by conflict), sebab di manapun dan kapanpun dalam suatu organisasi, konflik merupakan suatu keniscayaan (pasti ada dan tidak mungkin untuk dihindari walaupun kapasitas konflik itu ringan).

Penyelesaian konflik di pesantren mahasiswa sebagaimana perilaku di atas lebih dominan pada kategori lumping (bersabar), karena para pimpinan menganggap bahwa terjadinya konflik itu diakibatkan oleh informasi yang tidak sampai kepada mereka (miscommunication), sehingga akses hukumnya dianggap tidak valid (Nader dan Todd dalam Condiffe :1995, Rivai: 2003). Bahkan di beberapa pesantren, kyai dan pengurus berusaha menghindari konflik internal (avoidance). Keputusan untuk meninggalkan konflik itu didasarkan kepada perhitungan bahwa konflik yang terjadi atau dibuat tidak memiliki kekuatan secara sosial, namun penyelesaian yang sering dilakukan oleh majelis pengasuh adalah mediasimelalui pengurus harian dan para kyai muda serta klarifikasi (tabayyun) terhadap persoalan yang fakum (mauquf).

c. Pembangun tim (team building) di pesantren mahasiswa
Pembangunan tim dalam organisasi pesantren mahasiswa adalah mutlak, sebab Rasulullahpun mengajarkan sholat berjamaah yang pahalanya 27 derajat dibanding dengan sholat sendirian, termasuk dalam melakukan kegiatankegiatan di pesantren mahasiswa. Dalam Pembangunan tim dilakukan melalui proses pertemuan dan pemerataan komunikasi di antara pengurus, pemanfaatan moment-moment, pelibatan para organisasi santri yang bertujuan sebagai perbaikan dan peningkatan mutu pesantren mahasiswa. Dapat ditafsirkan bahwa media komunikasi sangat penting keberadaannya di pesantren mahasiswa. Sebagaimana dikatakan Hamzah (1978) bahwa media komunikasi, merupakan hal yang sangat memungkinkan bagi pemimpin untuk berinteraksi dengan koleganya, yakni; pertemuan melalui media massa, baik cetak maupun eletronik, pemimpin bisa menggunakan koran, majalah, tabloid, radio, televisi, film (atau media lainnya yang lebih teknologis). Media ini cukup membantu dalam proses mediasi dan komunikasi yang efektif.

3.Nilai spiritual kepemimpinan dalam budaya organisasi pesantren mahasiswa

a. Ragam nilai kepemimpinan spiritual di pesantren mahasiswa

Ragam nilai kepemimpinan spiritual dalam budaya organisasi pesantren mahasiswa terdapat perbedaan skala prioritas nilai (scale priorities of value) pada warga pesantren mahasiswa dapat dikatakan suatu hal yang wajar, sebab istilah "nilai" merupakan sebuah istilah yang tidak mudah untuk diberikan batasan secara pasti. Ini disebabkan karena nilai merupakan sebuah realitas yang abstrak (Ainbroisje dalam Kaswardi, 1993). Menurut Rokeach dan Bank (Thoha, 1996), nilai adalah suatu tipe 
kepercayaan yang berada dalam ruang lingkup sistem kepercayaan di mana seseorang bertindak atau menghindari suatu tindakan, atau mengenai suatu yang pantas atau tidak pantas dikerjakan. Ini berarti hubungannya dengan pemaknaan atau pemberian arti suatu objek. Nilai juga dapat diartikan sebagai sebuah pikiran (idea) atau konsep mengenai apa yang dianggap penting bagi seseorang dalam kehidupannya (Fraenkel dalam Thoha, 1996). Selain itu, kebenaran sebuah nilai juga tidak menuntut adanya pembuktian empirik, namun lebih terkait dengan penghayatan dan apa yang dikehendaki atau tidak dikehendaki, disenangi atau tidak disenangi oleh seseorang.

Allport, sebagaimana dikutip oleh Kadarusmadi (1996; 55), menyatakan bahwa nilai adalah: "a belief upon which a man acts by preference. It is this a cognitive, a motor, and above all, a deeply propriate disposition ". Artinya, nilai itu merupakan kepercayaan yang dijadikan preferensi manusia dalam tindakannya. Manusia menyeleksi atau memilih aktivitas berdasarkan nilai yang dipercayainya. Pada kepemimpinan spiritual maka nilai-nilai spiritual yang dilakukan oleh masing-masing orang biasanya memang berbeda, seperti seseorang jika menjadi seorang pemimpin, maka nilai spiritual apa yang ada pada dirinya dan ketertarikan nilai apa yang dia pandang suatu hal yang baik pada orang lain seandanya menetapkan nilai itu. Ragam nilai spiritual ini merupakan nikmat yang sangat luar biasa dari Allah SWT. Karena dengan ragam nilai, maka tidak terjadi kejenuhan dalam suatu kepemimpinan.

b. Sistem nilai kepemimpinan spiritual di pesantren mahasiswa

Pada dasarnya, semua orang memiliki hirarki nilai yang membentuk sistem nilai pribadinya. Sistem ini dapat diketahui melalui pandangan orang tentang tingkat kepentingan suatu nilai seperti kemerdekaan (kebebasan), kesenangan, harga diri, kejujuran, kepatuhan, dan kesamaan (equality). Untuk mengetahui atau melacak sebuah nilai harus melalui pemaknaan terhadap kenyataan-kenyataan lain berupa tindakan, tingkah laku, pola pikir dan sikap seseorang atau sekelompok orang. Budaya organisasi yang terwujud dalam filosofi, ideologi, nilai-nilai, asumsi, keyakinan serta sikap dan norma organisasi mengikat anggota menjadi suatu kesatuan yang utuh dan akan selalu diajarkan/ disampaikan kepada setiap anggota baru yang tergabung dalam organisasi tersebut (Ekosusilo, 2003). Pesantren mahasiswaunggul dalam sistem nilai sangat besar pengaruhnya terhadap keunggulan organisasi pesantren mahasiswa itu sendiri. Sebagaimana dikatakan oleh Owens (1995) bahwa nilainilai, keyakinan, budaya, dan norma perilaku lebih berpengaruh terhadap kinerja individu dan organisasi. Nilai-nilai adalah pembentuk budaya dan merupakan dasar atau landasan bagi perubahan dalam hidup pribadi maupun kelompok. Sistem nilai dalam budaya organisasi pesantren mahasiswa itulah yang menuntun perilaku para anggotanya dalam memimpin dan mengelola pesantren mahasiswaagar menjadi lebih baik.

c. Hambatan dan solusi penerapan nilainilai kepemimpinan spiritual

Dapat dipahami terdapat beberapa hambatan dan solusi penyesaian dalam kepemimpinan spiritual di pesantren mahasiswa merupakan hal biasa dalam suatu organisasi. Dengan dilakukan komunikasi yang intens oleh top leader, hambatan justru akan menjadi kekuatan dalam organisasi pesantren mahasiswa. Komunikasi dalam organisasi mutlak untuk dilakukan, sebab komunikasi akan 
mempelancar informasi dan segala bentuk peran dan fungsi dalam organisasi pesantren mahasiswa. Sedangkan pada top leader harus memiliki minimal tiga keterampilan yakni; (1) conceptual skills/keterampilan konsep, (2) technical skills/keterampilan teknis, dan (3) humanical skills/keterampilan hubungan insani atau kemanusiaan (Pidarta, 2003).

\section{Hasil/Temuan Penelitian}

Analisis lintas situs dilakukan dengan cara memadukan dan mengkomparasikan temuan dari ketiga situs penelitian. Prosedur ini mengacu pada metode komparatif konstan. Dengan menggunakan metode tersebut, temuan penelitian pada situs I dirumuskan dalam bentuk proposisi. Selanjutnya proposisi tersebut dikomparasikan dan dipadukan dengan proposisi situs II yang juga disusun berdasarkan temuan penelitian. Hasil pengujian dari kedua situs tersebut, selanjutnya diuji dan dikomparasikan pula dengan proposisi dari situs III sehingga diperoleh proposisi lintas situs. Hasil akhir dari proses tersebut dijadikan temuan teoritik penelitian. Dalam proses analisis lintas situs ini dilakukan pengkajian terhadap ketiga situs penelitian tersebut, terutama dari sisi kesamaan-kesamaan dan keunikan dengan mengacu pada masing-masing latar, maka diperoleh hasil/ temuan penelitian lintas situs sebagai berikut:

1. Tipologi Kepemimpinan

a. Perspektif kepemimpinan spiritual di Pesantren Mahasiswa

Kepemimpinan spiritual pesantren mahasiswa merupakan organisasi yang beranggotakan para pimpinan struktural universitas (rektorat) dan atau yayasan serta beberapa kyai senior kemudian disebut sebagai "majelis pembina atau majelis pengasuh" sebagai badan tertinggi di pesantren mahasiswa, secara fungsinya sebagai kepemimpinan (leadership style) dan kepengasuhan (parenting style) merupakan pembina pengurus harian dan sebagai pemimpin serta pengasuh santri mahasiswa pada organisasi pesantren mahasiswa.

b. Spiritualitas Kepemimpinan

Spiritualitas kepemimpinan pada majelis pengasuh teraktualisasi dalam mempengaruhi orang yang dipimpin dengan cara memotivasi agar memiliki semangat yang tangguh pada bawahan dan warga pesantren mahasiswa, mencerahkan suasana dengan menciptakan atmosfer organisasi yang kondusif, pengarah visi/misi/tujuan organisasi agar terfokus, membangkitkan semangat untuk meningkatkan kualitas sumber daya manusia warga pesantren mahasiswa melalui keterampilan hidup (lifeskill) dan peningkatan keilmuan dan pengamalan keagamaan, memampukan kemandirian santri dengan memberikan sarana prasarana pesantren mahasiswa dan meningkatkan pemasukan para ustadz untuk menambah kesejahteraan mereka, secara makro sebagai upaya untuk mewujudkan visi, misi dan tujuan organisasi pesantren mahasiswa menjadi semakin maju dan bermutu serta memberikan kontribusi pada masyarakat, bangsa dan Negara serta agama dilandasi dengan nilai-nilai spiritualitas keagamaan Islam.

c.Tipologi Kepemimpinan Spiritual

Tipologi kepemimpinan yang dilakukan oleh majelis pengasuh dan pengurus harian pesantren mahasiswa, berkecenderungan pada perilaku kepemimpinan kolegial partisipatif demokratis -religio spiritual. Karena kepala pesantren mahasiswa ditunjuk berdasarkan SK. Rektor/Yayasan, maka secara legal formal dalam menjalankan tugas-tugas senantiasa partisipasi dukungan oleh semua pihak dan 
pembuatan keputusan secara demokratis sangat menonjol dengan melibatkan kepala-kepala bidang serta didasarkan atas nilai-nilai spiritual Islam.

2. Tugas dan fungsi kepemimpinan dalam proses; pengambilan keputusan, Pengendalian konflik, dan pembangun tim

a. Pengambilan keputusan (decision making)

Pengambilan keputusan majelis pengasuh dan atau pengurus harian dilakukan melalui musyawarah dan inisitif-inisiatif sebagai proses penetapan tujuan dan sosialisasi program dalam memperkaya gagasan dan keterlibatan semua pihak. Mudir Ma'had dalam membuat program kerja tahunan selalu melibatkan kepala bidang-kepala bidang, dengan cara masing-masing bidang secara komisi merapatkan terlebih dahulu program-programnya, setelah masingmasing bidang itu menghasilkan kosep. Kemudian masing-masing bidang menyampaikan program-programnya dengan cara diplenokan, sehingga program-program itu dapat diketahui oleh masing-masing bidang atau biasanya terdapat saran-saran yang dilontarkan antar bidang. Setelah fit semua program kerja keseluruhan bidang, selanjutnya Mudir Ma'had (kepala pesantren mahasiswa) mengetuk palu tiga kali sebagai bentuk disahkannya hasil pleno, yang kemudian disosialisasikan ke warga pesantren mahasiswa, sehingga semua warga pesantren mahasiswa mengetahui dan banyak yang mendukung.

b. Pengendalian konflik (conflict control)

Penyelesaian konflik bersifat individual, mediasi, klarifikasi (tabayyun), proses ikrar dan perjanjian (tajdidun niyah), dan proses meja hijau (mahkamah), sebagai upaya penegakan syari'ah. Cara ini dirasa sangat efektif. Secara individu, masalah dapat diselesaikan karena seringkali yang namanya konflik itu hanya kasuistik pada seseorang, sedangkan mediasi dengan menggunakan media bisa teman dekatnya atau orang tuanya dipanggil. Apabila ada pengaduan dari warga pesantren, maka mahasiswa diklarifikasi (tabayyun) terlebih dahulu agar tidak terjadi fitnah sembari mencari solusi terbaik. Bila ada konflik antar individu seperti bertengkar, maka kedua belah pihak harus berikrar dan menulis perjanjian di kertas yang dibubuhi dengan materai atau istilahnya tajdidun niyah. Sedangkan kalau masalah itu merupakan pelanggaran yang sangat berat, maka santri mahasiswa diproses ke meja hijau secara internal pesma, namun jika efeknya dengan pihak lain dan pelanggaran yang berunsur pidana berat diserahkan kepada pihak yang berwajib. Namun pelanggaran atau konflik yang seberat itu di pesantren mahasiswa tidak pernah terjadi. nauzu billah mindzalik.

c. Pembangun tim (team building).

Pembangunan tim dalam organisasi pesantren mahasiswa ini adalah mutlak, sebab Rasulullahpun mengajarkan sholat berjamaah yang pahalanya 27 derajad dibanding dengan sholat sendirian, termasuk dalam melakukan kegiatan-kegiatan di pesantren mahasiswa. Pembangunan tim dilakukan melalui proses pertemuan dan pemerataan komunikasi di antara pengurus, pemanfaatan moment-moment, pelibatan para organisasi santri yang bertujuan sebagai perbaikan dan peningkatan mutu pesantren mahasiswa.

3. Nilai spiritual Kepemimpinan dalam budaya organisasi pesantren mahasiswa a. Ragam nilai kepemimpinan spiritual di Pesantren Mahasiswa

Ragam nilai kepemimpinan spiritual dalam budaya organisasi pesantren mahasiswa terdapat perbedaan skala nilai prioritas (scale priorities) pada warga pesantren mahasiswa, sebab 
kekuasaan dan otoritas masing-masing warga berbeda. Pada Majelis Pengasuh adalah ketaqwaan, shidiq(benar/jujur),, amanah, tabliqh, fathonah, istiqomah, ikhlas, berani (sajaah), bersyukur pada Allah SWT dan tidak boleh ketinggalan adalah memberikan contoh yang baik atau uswah kepada semua pihak, taqwa (memiliki kesehatan ruhani), kesehatan jasmani, bersyukur kepada Allah, iffah (malu melakukan dosa), memiliki kecerdasan emosional, bersikap sabar, bersikap optimis, berjiwa besar, bersikap saja'ah (berani), egaliter (kesederhanaan), jihad, tawadlu' (etis/rendah hati dan menghormat), uswah (teladan), kualitas, akhlak mulia, humanis (kekeluargaan dan persahabatan), populis, dan kedisiplinan.

b. Sistem nilai kepemimpinan spiritual

Sistem nilai kepemimpinan spiritual dalam budaya organisasi pesantren mahasiswa Ulul Yaqin terdapat kesepakatan nilai yang dianut bersama pada warga pesantren mahasiswa, karena sumber yang dipakai sama yakni; AlQur'an, Al-Hadits, Ijma', dan Qiyas. Dengan demikian, seperti taqwa maka semuanya menginginkan ketaqwaan itu, dan begitu pula disiplin, jujur, maka semuanyapun juga menginginkan seperti itu dan sebagainya.

c. Hambatan dan solusi penerapan nilainilai kepemimpinan spiritual

Dapat dipahami bahwa memang terdapat beberapa hambatan dan solusi penyelesaian dalam kepemimpinan spiritual di pesantren mahasiswa, tetapi yang patut disadari adalah fenomena itu merupakan hal yang biasa dalam suatu organisasi. Dengan dilakukan komunikasi yang intens oleh top leader, hambatan justru akan menjadi kekuatan dalam organisasi pesantren mahasiswa.

\section{Kesimpulan dan Saran}

1. Kesimpulan
a.Tipologi kepemimpinan di pesantren mahasiswa perspektif kepemimpinan spiritual di pesantren mahasiswa. Pengurus harian pesantren mahasiswa (Ma'had) dipimpin oleh seorang Mudir (Kepala Pesantren), wakil Mudir, sekretaris, bendahara dan beberapa Kepala Bidang (Kabid).

b.Spiritualitas kepemimpinanpada majelis pengasuh teraktualisasi dalam mempengaruhi orang yang dipimpin dengan cara memotivasi agar memiliki semangat yang tangguh pada bawahan dan warga pesantren mahasiswa, mencerahkan suasana dengan menciptakan atmosfer organisasi yang kondusif, pengarah visi/misi/tujuan organisasi agar terfokus dan membangkitkan semangat untuk meningkatkan kualitas sumber daya manusia warga pesantren mahasiswa

c. Tipologi kepemimpinan spiritualberkecenderungan pada perilaku kepemimpinan kolegialpartisipatif -demokratis -religio spiritual.

d. Tugas dan fungsi kepemimpinan spiritual dalam proses pengambilan keputusan, pengendalian konflik dan pembangunan tim

2. Saran-saran

Dari hasil temuan dan kesimpulan penelitian, maka beberapa saran yang perlu diperhatikan sebagai berikut:

a. Pengelola dan para kyai di pesantren mahasiswa, hendaknya semakin menyadari bahwa sejarah pesantren tumbuh dan berkembang atas kebutuhan masyarakat (communty education), sehingga pengembangan pesantren di masa-masa mendatang dikembalikan atas dasar kebutuhan masyarakat dengan memberikan peluang dan kesempatan kepada masyarakat (stakeholder) untuk berpartisipasi dan berkontribusi sesuai 
dengan kebutuhan pesantren dan masyarakat.

b. Bagi Departemen Agama/Kementerian Agama sebagai leading sector utama pengembangan pesantren, hendanya semakin mengarahkan pesantren sebagai lembaga pendidikan masa depan (center for excelence) masyarakat melalui peran-peran Seksi Pendidikan Keagamaan dan Pondok Pesantren (PEKAPONTREN) yang bernuansa pendidikan antrophocentrisme dan theocentrisme, sehingga menjadi lembaga pendidikan alternatif masyarakat berbasis nilai keislaman (religiouscentris).

c. Bagi Pemerintah Daerah Kota/Kabupaten, yang dalam hal ini adalah Disdik pada Kasi Pendidikan Non Formal hendaknya memandang pesantren sebagai lembaga sosial pendidikan dan pemberdayaan, sehingga senantiasa mendorong terbentuknya PKPM (Pusat Kegiatan Belajar Masyarakat) melalui masyarakat secara kultural informal, dan manfaat pesantren semakin luas menjadi mitra pemberdayaan masyarakat yang berbasis religious.

\section{DAFTAR PUSTAKA}

Al Qur'an dan Terjemahannya, Departemen/ Kementerian Agama RI

A'la, Abd, 2006, Pembaruan Pesantren, , Yogyakarta: Pustaka Pesantren

Al-Amien, 2003, Panduan Lustrum IV Insitu Dirosat Islamiyah Al-Amien, Parenduan: alamienprinting, Prenduan

Al-Amien, 2006, Warkat-Jurnal Informasi Tahunan Pondok Pesantren Al-Amien Prenduan, Sumenep: Al-Amien Printing
Amin, M. 1995, Dinamika Islam: Sejarah Transformasi dan Kebangkitan Ulama, Yogyakarta: LKPSM

Antonio, S., M., 2007, Muhammad saw; The Super Leader Super Manager, Jakarta: Tazkia Mulimedia \& ProLM Center

Arifin, I. 1993, Kepemimpinan Kyai (Kasus Pondok Pesantren Tebuireng), Malang: Kalimasahada

Arifin, I. 1996, Penelitian Kualitatif Dalam Ilmu-IImu Sosial dan Keagamaa, Malang : Kalimasahada

Atiqullah, 2006, Dasar-Dasar Psikologi Agama, Pamekasan: STAIN Pamekasan Press.

Atiqullah. 2004, Reorientasi Sistem Pendidikan Pondok Pesantren; Dari Sistem Pendidikan Khalaf kepada Sistem Pendidikan Khalaf, Tesis tidak diterbitkan, Surabaya: Program Pascasarjana UNESA Surabaya

Atiqullah. 2009. Prilaku Kepemimpinan Kolektif (Studi Multi Situs pada Pesantren Bani Djauhari, Pesantren Bani Syarqawi Sumenep, dan Pesantren Bani Basyaiban Pasuruan). Disertasi tidak diterbitkan, Malang ; Program Pascasarjana Universitas Negeri Malang.

Bakhri, S., M., 2004, Kebangkitan Ekonomi Syariah di Pesantren, Belajar dari Pengalaman Sidogiri, Pasuruan: Cipta Pustaka Utama

Barton, G. 1999, Gagasan Islam Liberal di Indonesia, Jakarta Paramadina/Pustaka Antara

Bawani, I. 1987, Segi-segi Pendidikan Islam, Surabaya: Al-Ikhlas 
Bennis, G., W., 1959, Leadership Theory and Administrative Science Quartely. Desember

Bennis, W. G dan Nanus, B. 1985, Leaders; The Strategi for Taking Change, New York: Harper and Row

Bogdan, R. C. \& Biklen, S. K. 1998, Qualitative Research in Education, an Introduction Theory and Methods, USA: Library of Congress Catalogingin-Publication Date

Carolyn S., A. 1982, The Search for School Climate, Review of Education Research

Clegg, B., dan Birch, P., 2006, Instans Teamwork. Jakarta: Erlangga

Compbell, J.P., 1970, Managerial Behaviour, Performance, and Effectiveness, New York, Mc. Graw Hill Coy.

Condiffe, P., 1995, Conflict Management; a Practicle Guide, Kuala Lumpur: S. Abdul Majeed \& Co

Cooper, K., R., \& Sawaf, A., 1997, Executive $E Q$, Emotional Intelegence in Leadership an Organizations, New York: LLC

Creswell, J., W., 1994, Research Design: Qualitative and Quantitative Approaches, USA: Library of Congress Cataloging-in-Publication Date

Crompton, S., W., 2001, 100 Spritual Leaders Who Shaped Word History California: Bluewood Books

Departemen Agama RI, 1985, Al-Qur'an dan Terjemahnya, Semarang: Asy Syifa'

Dhofier, Z., 1996, Tradisi Pesantren : Studi Tentang Pandangan Hidup Kyai, Jakarta: LP3ES
Dirdjosanjoto, P., 1999, Memelihara Umat : Kyai Pesantren-Kyai langgar di Jawa, Yogyakarta : LkiS

Duncan, J., W., 1981, Organizational Behaviour, Boston, Houghton Mifflin Coy.

Effendy, B., 1990, Annuqoyah; Gerak Tranformasi Sosial di Madura, Jakarta : P3M

Effendy, M., 1985, Manajemen; Suatu Pendekatan Berdasarkan Ajaran Islam, Palembang

Eksan, M.,. 2000, Kyai Kelana :Biografi Kyai Muchid Muzadi, Yogyakarta : LKIS

Faesol A., 2006, Persepsi Masyarakat Tentang Kiai, Studi Kasus atas Persepsi Masyarakat Prenduan Pesisir tentang Kiai Pondok Pesantren Al-Amien Prenduan, IDIA Sumenep

Fremont K., E., dan Rosenzweig, E., J., 1970, Organization and Management, A System Approach, New York : McGraw-Hill Book Company

Hamzah, L., A., 1978, Al-I'lan fi Shadr alIslam, Daar al-Fikr al-Arabi, KairoMesir

Hanun A. 1999, Sejarah Pendidikan Islam, Jakarta : Logos Wacana Ilmu

Hasbullah, 1998, Sejarah Pendidikan Islam di Indonesia, Jakarta : LKIK

Horikoshi, H., 1976. A Traditional Leader in a Time of Change: The Kijaji and Ulama in West Java, The University of Illinois at Urbana-Chapaign, USA, penterjemah Umar Basalim dan Andi Muarly Sunrawa, , 1987, Kyai dan Perubahan Sosial, Jakarta : LP3ES 
Hoy, W., K., \& Miskel, G., C., 2001, Educational Administration, Theory, Research and Practice, Singapore : McGraw-Hill

Ibrahim, S., dan Malik, D., D., 1997, Hegemoni Budaya Yogyakarta : Yayasan Bentang Budaya

Kamisa, 1997, Kamus Lengkap Bahasa Indonesi, Surabaya : Kartika

Kartodirjo, S., 1984, Kepemimpinan Dalam Dimensi Sosial, Jakarta: LP3ES

Komariah, A., dan Cepi, T., 2005, Visionary Leadership, Menuju Sekolah efektif, Jakarta: Pt. Bumi Aksara

Kosim, M. 2003, Pondok Pesantren di Pamekasan (Pertumbuhan dan Perkembangannya), Pamekasan: P3M STAIN Pamekasan

Liliweri, A., 1997, Sosiologi Organisasi, Bandung: Citra Aditya Bhakti

Maarif., S., 1997, Islam: Kekuatan Doktrin dan Keagamaan Umat, Yogyakarta: Pustaka Pelajar

Madjid, N., 1997, Bilik-Bilik Pesantren, Sebuah potret Perjalanan, Jakarta, Paramadina

Maksum, 1999, Sejarah Madrasah dan Perkembangannya, Jakarta:Logos Wacana Ilmu

Mandux, B., R., 2001, Kiat Membangung Tim Handal, Jakarta: Airlangga

Mantja, W., 2007, Profesionalisme Tenaga Kependidikan: Manajemen Pendidikan dan Supervisi Pengajaran, Malang: Elang Mas

March., G., J., dan Simon, A., H., 1959, Organization,New York :John Wiley \& Sons Inc

Mas'ud, A., 2006, Dari Haramain Ke Nusantara : Jejak Intelektual Arsitek
Pesantren, Jakarta: Penerbit Kencana Prenada media Group

Mastuhu, 1994, Dinamika Sistem Pendidikan Pesantren: Suatu Kajian Tentang Unsur dan Nilai Sistem Pendidikan Pesantren, Jakarta: INIS

Mastuhu. 1999, Meberdayakan Sistem Pendidikan Islam, Jakarta: Logos Wacana Ilmu

Merle, C., J., (ed), Handbook af Organizational Performance, Jakarta : Pt. RajaGrafindo Persada

Michael H. H., 1994, Seratus Tokoh yang Paling Berpengaruh dalam Sejarah (Terj. H. Mahbub Djunaidi), Jakarta: Pustaka Jaya

Miles, B., M., dan Huberman, M., A., 1992, Qualitative Data Analysis, (Terjemahan Tjetjep Rohendi Rohidi), Jakarta: UI-Press

Moleong, J., L., 2004, Metodologi Penelitian Kualitatif, Bandung: Remadja Rosda Karya

Muhadjir, N., 1996, Metodologi Penelitian Kualitatif, Yogyakarta: Rake Serasin

Mulkhan, M., A., 1998, Rekonstruksi Pendidikan dan Tradisional Pesantren: Religiusitas IPTEK, Yogyakarta: Pustaka Pelajar

Munandar, S., A., (Eds). 2004, Peran Budaya Organisasi dalam Peningkatan Unjuk Kerja Perusahaan, Bag. Psikologi Industri \& Organisasi, Jakarta : Fak. Psikologi UI

Munandar, S., A., 2004, Peran Budaya Organisasi dalam Unjuk Kerja Perusahaan, Jakarta: Bagian Psikologi Industri dan Organisasi, Fak. Psikologi UI Jakarta 
Nanus, B., 2001, Kepemimpinan Visioner, Jakarta: Prenhallindo

Nata, A., 2000, Peran Para Tokoh Pendidikan Islam : Seri Kajian Filsafat Pendidikan Islam, Jakarta: Raja Grafindo Persada

OMIM, 2006, Jejak Langkah Sembilan Masyayikh Sidogiri, Pasuruan: OMIM Sidogiri

Ouchi, W., 1981, Theory Z: How American Business Can Meet the Japaness, Addison-Wesley

Owens, R., G, 1987, Organzational Behavior in School, The United States of America

Rahardjo, M., D., 1995, Pesantren dan Pembaharuan, Jakarta:LP3ES

Rachmat Ramadhana Al Banjari, 2008. Prophetic Leadership. Jogjakarta: DIVA Press.

Ramdhani, A., dan Suryadi, K., 1998, Sistem Pendukung Keputusan: Suatu Wacana Struktural Idealisasi dan Implementasi Konsep Pengambilan Keputusan, Bandung: PT. Remaja Rosdakarya

Rivai, V., 2003, Kepemimpinan dan Perilaku Organisasi Jakarta:RadjaGrafindo Persada

Robbins, S., P., 2003, Organizational Behavior, (Terjemahan oleh Tim Indeks),Jakarta:Gramedia

Rofiq A., 2005, Pemberdayaan Pesantren, Menuju Kemandirian dan Profesionalisme Santri dengan Metode Daurah Kebudayaan, Yogyakarta: LkiS

Salim A., 2001, Teori dan Paradigma Penelitian Sosial, Yogyakarta: Tiara Wacana
Shodiq, J., 2006 al-Ma'hadu wa Sa'iluhu fi Nadzari al-Fiqhi (Fiqhi Pesantren), Pasuruan : Pustaka Sidogiri

Sinn, I., Abu., 2007, al-Idarah fi al-Islam, Tarjemah; Dimyauddin Juwaini, Jakarta : RadjaGrafindo Persadans

Soekanto, S., 1984, Beberapa Teori SosiologiTentang Struktur Masyarakat Jakarta: Penerbit Radar Jaya Ofsett

Soekanto, S., 2002, Sosiologi, Suatu Pengantar, Jakarta: RadjaGrafindo Persada

Soetopo, H., 1982, Kepemimpanan dan Supervisi Pendidikan, Surabaya: Bina Aksara

Sonhadji, A., 1977, Dasar-Dasar Penelitian Kualitatif,Makalah Seminar Penelitian Kuantitatif dan Kualitatif, Malang: PPS IKIP Malang

Stanbrink, A., K., 1994, Pesantren, Madrasah dan Sekolah : Pendidikan Islam Dalam kurun Moder, Jakarta:LP3ES

Suaidi, A., 2002, Pergulatan Pesantren dan Demokratisasi, Jakarta:LKiSdan P3M

Suhandijah, 1993, Pengembangan dan Inovasi Kuriukulum, Jakarta:RajaGrafindo Persada

Sukamto, 1999, Kepemimpinan Kiai dalam Pesantren, Jakarta: LP3ES

Syaifuddin, A., M., 1993, Desekularisasi Pemikiran; Landasan Islamisasi Bandung: Penerbit Mizan.

Tabroni. 2005. The Spiritual Leadership ( Pengefektifan Organisasi Noble Industry Melalui Prinsip-Prinsip Spiritual Etis). Malang: UMM Press.

Tagiuri, R., 1968, Organizational Climate; Exploration of a Concept, Boston: Harvard University 
Taliiduha, T., 2003, Budaya Organisasi, Jakarta: Renika Cipta

Tamassya, 2007, Laporan Tahunan Pengurus Pondok Pesantren Sidogiri Periode 1427-1428 H, Pasuruan: PP. Sidogiri

Tamassya, 2008, Laporan Tahunan Pengurus Pondok Pesantren Sidogiri Periode 1428-1427 H, Pasuruan: PP. Sidogiri

Thoha, Miftah., 1996, Perilaku Organisasi, Konsep Dasar dan Aplikasinya, Jakarta: RadjaGrafindo Persada

Tyson, S., and Jackson, T., 1992, The Essence of Organizational Behaviour Prentice Hall International

Universitas Negeri Malang, 2000, Pedoman Penulisan Karya Ilmiah. Malang:. Penerbit Universitas Negeri Malang

Usman, H., 2006, Manajemen, Teori, Praktik, dan Riset Pendidikan, Jakarta: Pt. Bumi Aksara

Wahid A., Z., 1994, Dunia Pemikiran Kaum Santri, Yogyakarta: LK PSM NU DTY

Wijayakusuma, K., M., dan Yusanto, I., M., 2003, Pengantar Manajemen Syari'ah, Jakarta: Khairul Bayan

Yukl, A., G., 1994, Leadership in Organizations. (Terjemahan Yusuf Udaya). Jakarta:. Prenhallindo

Zarkasyi, I., 1996, Merintis Pesantren Modern, Ponorogo: PP. Gontor Press

Zuhairini dkk. 1997, Sejarah Pendidikan Islam, Jakarta: Bumi Aksara. 